Original Research Article

\title{
In vitro evaluation of combination effects of doxorubicin with methylxanthine fractions isolated from Bancha and Pu-erh teas against breast cancer cells
}

\author{
Kaloyan D. Georgiev ${ }^{1}$, Iliya J. Slavov², Ivan A. Iliev ${ }^{3}$
}

${ }^{1}$ Department of Pharmaceutical Technologies, ${ }^{2}$ Department of Biology, Faculty of Pharmacy, Prof. Paraskev Stoyanov Medical University, Varna, Bulgaria

${ }^{3}$ Institute of Experimental Morphology, Pathology and Anthropology with Museum, Bulgarian Academy of Sciences, Sofia, Bulgaria

Received: 18 July 2019

Revised: 20 August 2019

Accepted: 20 August 2019

*Correspondence to:

Dr. Kaloyan D. Georgiev, Email: kalgeorgiev@ hotmail.com

Copyright: (C) the author(s), publisher and licensee Medip Academy. This is an openaccess article distributed under the terms of the Creative Commons Attribution NonCommercial License, which permits unrestricted noncommercial use, distribution, and reproduction in any medium, provided the original work is properly cited.

\begin{abstract}
Background: In the present study we investigated the combination effects of anthracycline antibiotic, doxorubicin, with methylxanthine fractions isolated from Bancha and Pu-erh tea leaves, against MCF-7 and MDA-MB-231 breast cancer cell lines.

Methods: Neutral red uptake assay was used for assessment of cytotoxicity effects and fractional effect analysis and combination index for evaluation of the combination effects.

Results: Doxorubicin was used in varying concentrations by a double dilution method, whereas the methylxanthine fractions were in fixed concentrations $100,200,400$ or $600 \mu \mathrm{g} / \mathrm{ml}$. Results have shown that methylxanthine fraction isolated from Bancha has synergic effects with doxorubicin, while methylxanthines from Pu-erh displayed antagonistic effects.

Conclusions: The obtained results lead us to suspect, that even minor differences in the composition of natural products can lead to significant differences in the biological activity of the product.
\end{abstract}

Keywords: Pu-erh, Bancha, Methylxanthine, Breast cancer, Combination effect, Synergism

\section{INTRODUCTION}

Methylxanthines, caffeine, theophylline and theobromine are found in the most commonly consumed beverages and foods worldwide. The main effects observed after consumption of methylxanthines include excitation of the central nervous system, strengthening of the heart activity and pulse increase, improvement of organ perfusion, bronchodilation, stimulation of urination and intestinal peristalsis. ${ }^{1}$ Although there are many mechanisms of action described, most pharmacological effects of methylxanthines result from a blockade of the adenosine receptors. ${ }^{2}$ The both used teas in our study - Pu-erh and Bancha, contain significant amounts of methylxanthines. ${ }^{3}$

Anthracycline antibiotic, doxorubicin, is widely used antineoplastic drug in the therapy of variety of human solid and hematological malignancies. ${ }^{4}$ Doxorubicin alone or in combinations is the mainstay therapy of the metastatic breast cancer. However, dose-limiting 
toxicities such as cardiotoxicity and bone marrow toxicity limit its widespread use.

To increase the therapeutic activity on one hand, and to reduce the adverse drug effects on the other hand, in the oncological practice, it is often recoursed the combination chemotherapy regimens. ${ }^{5}$ Therefore, the purpose of the present study is to evaluate combination effects of doxorubicin with methylxanthines isolated from $\mathrm{Pu}$-erh (MXP) and Bancha (MXB) teas against two breast cancer cell lines - MCF-7 and MDA-MB-231.

\section{METHODS}

\section{Plant material}

The air dried Pu-erh and Bancha tea leaves were purchased from the local market and the material was held at room temperature. They have been identified by Assoc. Prof. Iliya Slavov from the Department of Biology, Faculty of Pharmacy, Medical University of Varna, Bulgaria. Before extraction the obtained plant material was ground into small particles.

\section{Extraction of methylxanthines}

Accurately weighed amounts of $\mathrm{Pu}$-erh and Bancha tea leaves $(50 \mathrm{~g})$ were extracted under reflux with distilled water for $60 \mathrm{~min}$ and filtered through a Buchner funnel. The aqueous extracts were acidified with sulfuric acid and concentrated. The solution was extracted with chloroform in separating funnel. Chloroform extract was washed with sodium hydroxide solution and then with water. After evaporation of chloroform, a mixture of methylxanthines was obtained and its percentage yield was calculated. ${ }^{6}$

\section{Cell cultures}

The breast cancer cell lines MCF-7 (estrogen, progesterone receptors +, HER2-), and MDA-MB-231 (triple negative, ER-, PR-,HER-) cells were cultured in Dulbecco Modified Eagle's medium (DMEM) supplemented with $10 \%$ (v/v) fetal bovine serum (Gibco, Austria), $100 \mathrm{U} / \mathrm{ml}$ penicillin and $0.1 \mathrm{mg} / \mathrm{ml}$ streptomycin (Lonza, Belgium) under 5\% $\mathrm{CO}_{2}$ and $95 \%$ air atmosphere at $37^{\circ} \mathrm{C}$. Plastic flasks $25 \mathrm{~cm}^{2}$ supplied by Greiner, Germany, were used to grow the cells. The cells were kept in exponential phase of growth and after processing with trypsin-EDTA (FlowLab, Australia) they were seeded into 96-well plates $(100 \mu \mathrm{l} /$ well) at a density $1 \times 10^{4}$ cells $/ \mathrm{ml}$.

\section{Cell viability assay}

Cell viability was evaluated in MCF-7 and MDA-MB231 cells by neutral red uptake assay according to the standard protocol, with some modifications, which is based on the accumulation of the neutral red dye in lysosomes of viable cells. ${ }^{7}$ MCF-7 and MDA-MB-231 cells were seeded into 96-well plates. The cells were incubated with the used compounds for $72 \mathrm{~h}$, and cell viability was determined later. The treatment medium was replaced with DMEM containing $100 \mu \mathrm{g} / \mathrm{mL}$ neutral red dye and the cells were incubated for three hours. The optical density of the samples was measured by a microplate reader (TECAN, Sunrise TM, Groedig/ Salzburg, Austria) at $540 \mathrm{~nm}$. Cell viability was expressed as percent of control values.

\section{Analysis of drug combinations}

To evaluate the combination effects, we used fractional effect analysis (FA) or Bliss independence. ${ }^{8,9}$ The effect in this method is considered synergistic when the observed effect is greater than the effects of each individual agent. The equation used for calculating the combining effect $(\mathrm{CE})$ is:

$$
C E=\frac{A_{1} \times B_{2}}{100}
$$

Where $A_{1}$ and $B_{2}$ are inhibition percentages with single agents, expressed as percentage of the untreated control. For each concentration, we calculated the theoretical values, which we further compared with those we received actually: for $\mathrm{CE}_{\text {measured }}=\mathrm{CE}_{\text {calculated }}$ we conceded the effect as additive; for $\mathrm{CE}_{\text {measured }}<\mathrm{CE}_{\text {calculated }}$ as synergistic; and for $\mathrm{CE}_{\text {measured }}>\mathrm{CE}_{\text {calculated }}$ as antagonistic.

The second method we used was Chou-Talalay method. ${ }^{10}$ We recourse to this method, when we have observed significant synergistic effects, to confirm them. In our study, the CI values were determined for combination of doxorubicin and MXB using CalcuSyn ${ }^{\circledR}$ software (Biosoft, Cambridge, UK). ${ }^{11}$ A CI value less than 0.9 indicates synergism, CI equal to $0.9-1.10$ indicates additive interaction, and CI greater than 1.10 indicates antagonism.

\section{Statistical analysis}

The statistical evaluation was performed using GraphPad Prism 8.01 software (GraphPad Software, USA), and the significant differences between groups were analyzed using ANOVA. All results are expressed as arithmetic means \pm standard deviation (SD) of three separate experiments (each experiment was done with three parallels). A difference at $\mathrm{p}<0.05$ was considered statistically significant.

\section{RESULTS}

In our previous work, we defined the sensitivity of the used cell lines to doxorubicin. The both cell lines showed dose-dependent decreases in cell viability compared to the negative control (untreated cells). The $\mathrm{IC}_{50}$ value against MCF-7 cells were $0.07 \mu \mathrm{M}$, while against MDA-MB-231 were $0.79 \mu \mathrm{M}$ (Table 1$)$. 
Table 1: Doxorubicin $\mathrm{IC}_{50}$ values with $95 \%$ CI against MCF-7 and MDA-MB-231 cell lines.

\begin{tabular}{|l|ll|}
\hline & MCF-7 & MDA-MB-231 \\
\hline Doxorubicin & $0.07 \mu \mathrm{M}(0.02173$ & $0.79 \mu \mathrm{M}$ \\
IC $_{\mathbf{5 0}}(\mathbf{9 5 \%}$ CI $)$ & to 0.1160$)$ & $(0.25353-1,0654)$ \\
\hline
\end{tabular}

As can be seen on the Table 1, MCF-7 cells are approximately ten times more sensitive to the action of doxorubicin.

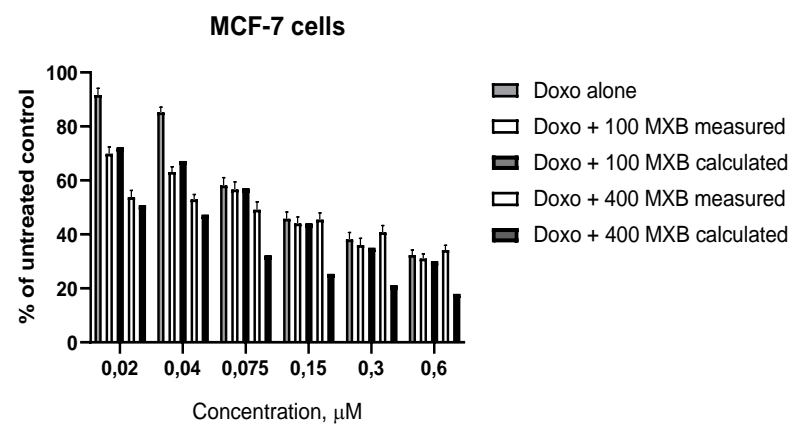

Figure 1: MCF-7 cells treated with Doxorubicin (Doxo) alone in concentration range 0.02-0.6 $\mu \mathrm{M}$ and in combination with 100 and $400 \mu \mathrm{g} / \mathrm{ml}$ methylxanthines isolated from Bancha (MXB).

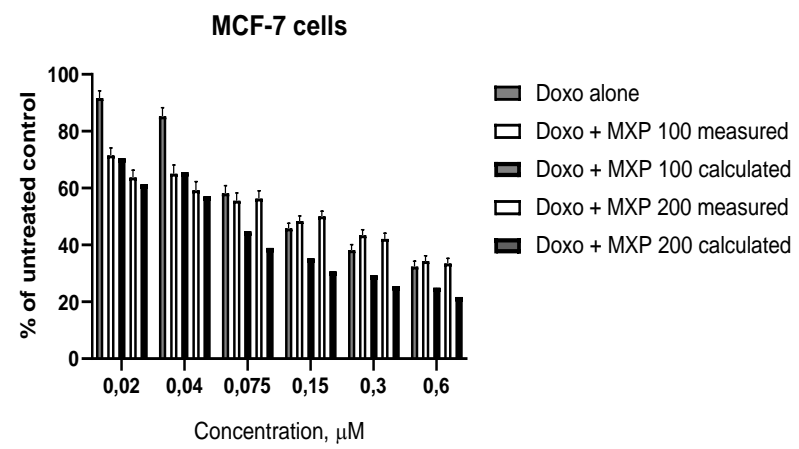

Figure 2: MCF-7 cells treated with Doxorubicin (Doxo) alone in concentration range 0.02-0.6 $\mu \mathrm{M}$ and in combination with 100 and $200 \mu \mathrm{g} / \mathrm{ml}$ methylxanthines isolated from Pu-erh (MXP).

To determine whether methylxanthine isolated from Bancha (MXB) and Pu-erh (MXP) could sensitizes MCF7 cells to treatment with doxorubicin, we cultured cells with doxorubicin at concentration range of 0.02 to 0.6 $\mu \mathrm{M}$, alone or in combination with fixed 100 and 400 $\mu \mathrm{g} / \mathrm{ml} \mathrm{MXB;} 100$ and $200 \mu \mathrm{g} / \mathrm{ml}$ MXP, for 72 hours. The cell proliferation was assessed using neutral red uptake assay. The results from treatment of MCF-7 cells are shown in Figure 1 and 2.

As can be seen from Figure 1, lower concentrations of doxorubicin $(0.02-0.04 \mu \mathrm{M})$ with $100 \mu \mathrm{g} / \mathrm{ml} \mathrm{MXB}$ have synergistic effects and with an increase in the concentrations of doxorubicin $(0.075-0.6 \mu \mathrm{M})$ the effects are additive. The usage of higher concentration of MXB $400 \mu \mathrm{g} / \mathrm{ml}$, leads to antagonistic effects. The situation with MXP was similar. We observe additive effects in lower concentrations of doxorubicin (0.02-0.04 $\mu \mathrm{M})$ with both used concentrations of MXP. With the other used concentrations the effects were antagonistic.

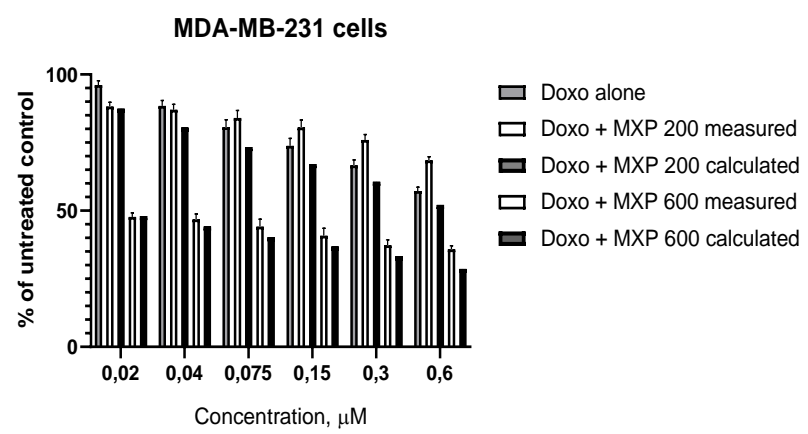

Figure 3: MDA-MB-231 cell line treated with Doxorubicin (Doxo) alone in concentration range 0.020.6 and in combination with 200 and $600 \mu \mathrm{g} / \mathrm{ml}$ methylxanthines isolated from Pu-erh (MXP).

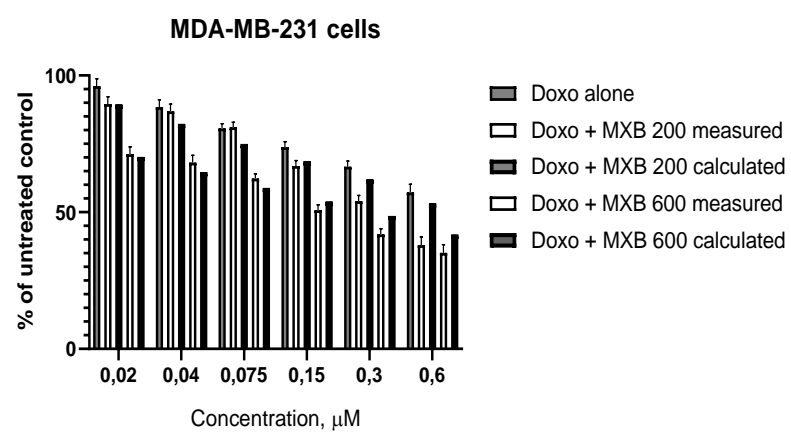

Figure 4: MDA-MB-231 cell line treated with Doxorubicin (Doxo) alone in concentration range 0.02$0.6 \mu \mathrm{M}$ and in combination with 200 and $600 \mu \mathrm{g} / \mathrm{ml}$ methylxanthines isolated from Bancha (MXB).

We tested combinations effects of doxorubicin and MXB and MXP on MDA-MB-231 cell line. Because MDAMB-231 cell line was more resistant to the action of doxorubicin, we used higher concentrations of methylxanthines - 200 and $600 \mu \mathrm{g} / \mathrm{ml}$. The results are presented on Figure 3 and 4.

The MXP only at the lowest concentration of doxorubicin $(0.02 \mu \mathrm{M})$ provided additive effects, all other concentrations showed antagonistic effects (Figure 3).

The situation with MXB was completely different. In the lower concentrations, doxorubicin (0.02-0.075 $\mu \mathrm{M})$ and MXB (200 and $600 \mu \mathrm{g} / \mathrm{ml}$ ) have additive effects, while in the highest concentrations $(0.15-0.6 \mu \mathrm{M})$ the combination is with significantly expressed synergistic effect (Figure 4). 
Table 2: Combination index after treatment of MDA-MB-231 cells with combination doxorubicin $(0.02-0.6 \mu M)+$ MXB (200 and $600 \mu \mathrm{g} / \mathrm{ml})$.

\begin{tabular}{|lllll|}
\hline $\begin{array}{l}\text { Doxorubicin } \\
\text { concentration }(\boldsymbol{\mu M})\end{array}$ & $\begin{array}{l}\text { MXB concentration } \\
(\mu \mathrm{gg} / \mathrm{ml})\end{array}$ & CI & $\begin{array}{l}\text { MXB concentration } \\
(\boldsymbol{\mu g} / \mathbf{m l})\end{array}$ & CI \\
\hline $\mathbf{0 . 0 2}$ & 200.0 & 1.20636 & 600.0 & 1.06166 \\
\hline $\mathbf{0 . 0 4}$ & 200.0 & 1.24558 & 600.0 & 1.03197 \\
\hline $\mathbf{0 . 0 7 5}$ & 200.0 & 1.21176 & 600.0 & 0.93512 \\
\hline $\mathbf{0 . 1 5}$ & 200.0 & 0.81526 & 600.0 & 0.73723 \\
\hline $\mathbf{0 . 3}$ & 200.0 & 0.76702 & 600.0 & 0.68348 \\
\hline $\mathbf{0 . 6}$ & 200.0 & 0.59957 & 600.0 & 0.75423 \\
\hline
\end{tabular}

CI: Combination index.

To confirm the observed synergistic effects, we used CalcuSyn ${ }^{\circledR}$ software, to calculate the combination index. The results are presented in Table 2.

The calculated combination index indicates that the combination of doxorubicin $(0.15-0.6 \mu \mathrm{M})$ and $\mathrm{MXB}$ (200 and $600 \mu \mathrm{g} / \mathrm{ml}$ ) allows synergistic effects.

\section{DISCUSSION}

The use of total extracts, fractions or pure substances of plant origin alone or in combination with approved drugs in the treatment of diseases is not something new and is already established in the pharmaceutical researches. Searching for such synergistic plant/herb-drug interactions, which could assist the therapeutic benefit or ameliorate the degree of adverse drug effects, is of particular importance for a field like oncology. ${ }^{12}$ Mehylxanthines, and especially the main component caffeine, are one of the most consumed natural products worldwide and they have been the subject of scientific researches frequently. ${ }^{13}$

Considering that the used methylxanthine fractions are rich in caffeine (the amount of caffeine in both fractions was determined by HPLC; results not published yet), we performed a literature review regarding the combination effect of caffeine with conventional antitumor drugs on tumor cells. The literature data have shown that there are various mechanisms, discussed as possible about the action of caffeine against tumor cells and their combination with other chemotherapeutic drugs. The most debated issues are the inhibition of DNA repair and the inhibition of efflux pumps. ${ }^{14-17}$ The both mechanisms suggest sensitizing the tumor cells to the action of cytotoxic drugs. On the other hand, there are data, that mehylxanthines ameliorate the pharmacological effects of aromatic anticancer compounds, such as doxorubicin, mitoxantron, topotecan, camptothecin, as well as other mutagenic agents. ${ }^{18-22}$ The possible mechanisms proposed by these authors include reducing the possibility of intercalation in the DNA strand and the direct formation of complexes of methylxanthines with aromatic compounds.
In our previously study, we demonstrated weakly expressed antiproliferative effects of MXP. ${ }^{6}$ We didn't find synergistic effects on MDA-MB-231 and HT-29 cell lines, when they were combined with oxaliplatin. Similar combination results are reported by other authors. Martins et al demonstrated synthesis of new derivative of caffeine, 6-selenocaffeine, which decreases the cytotoxic effects of oxaliplatin on MCF-7 cells, while increasing the activity of doxorubicin. ${ }^{23}$ Hertz et al showed antitumor activity of guarana (Paullinia cupana), which is rich in caffeine and catechins, on MCF-7 cells and increased antiproliferative effects when combining with conventional antitumor drugs, such as doxorubicin. ${ }^{24}$ The effect of the combinations on cell viability after 24 hours is significantly increased, while after 72 hours it transforms to synergetic antiproliferative effect. The authors suggest that other components, such as catechins, are responsible for these temporal changes. In the present study, the combination of MXP with doxorubicin did not provide synergistic effects. Hill et al explained that with possible interceptor role of caffeine, protecting cancer cell DNA from intercalation. ${ }^{25}$ Since the both methylxanthine fractions are similar in composition (as was mentioned above; results not published yet), we did not expect any different effects from MXB. However, the results we received invalidated our presumption. MXB, have shown a notable synergistic effect with doxorubicin on MDAMB-231 cell line, evaluated by the both used combination methods.

We have suggested, that even minor differences in the composition of a natural product, such as in our case, can lead to significant differences in the biological activity of the product, which requires follow-up studies to confirm this activity.

Funding: No funding sources Conflict of interest: None declared

Ethical approval: The study was approved by the Institutional Ethics Committee

\section{REFERENCES}

1. Nehlig A, Daval Jl Fau - Debry G, Debry G. Caffeine and the central nervous system: mechanisms of 
action, biochemical, metabolic and psychostimulant effects. Brain Res Brain Res Rev. 1992;17(2):139-70.

2. Fredholm BB, Bättig K, Holmén J, Nehlig A, Zvartau EE. Actions of caffeine in the brain with special reference to factors that contribute to its widespread use. Pharmacol Rev. 1999;51(1):83-133.

3. Georgiev K, Zhelev I, Georgieva S. Total phenolic compounds and tannins content of Bancha green tea (Camellia Sinensis) depending on extraction conditions. Scripta Scientifica Pharmaceutica. 2014;1(1):48-51.

4. Verrill M. Anthracyclines in breast cancer: therapy and issues of toxicity. The Breast. 2001;10(2):8-15.

5. Lee JH, Nan A. Combination Drug Delivery Approaches in Metastatic Breast Cancer. J Drug Delivery. 2012;2012:915375.

6. Georgiev K, Iliev I, Jelev I. Evaluation of antitumor effect of methylxanthine fraction isolated from $\mathrm{Pu}$ erh tea. WJPR. 2015;4(7):2236-42.

7. Borenfreund E, Puerner JA. A simple quantitative procedure using monolayer culture for toxicity assays. J. Tissue Cult. Meth. 1984;9:7-9.

8. Bliss CI. The toxicity of poisons applied jointly. Ann Appl Biol. 1939;26:585-615.

9. Webb JL. Enzyme and Metabolic Inhibitors. New York: Academic Press; 1963: 55-79.

10. Chou TC. Drug combination studies and their synergy quantification using the Chou-Talalay method. Cancer Res. 2010;70:440-6.

11. Chou TC, Hayball MP. CalcuSyn for Windows: multiple-drug dose-effect analyzer and manual. Cambridge (UK): Biosoft; 1997.

12. Pezzani R, Salehi B, Vitalini S, Iriti M, Zuñiga FA, Sharifi-Rad J, et al. Synergistic Effects of Plant Derivatives and Conventional Chemotherapeutic Agents: An Update on the Cancer Perspective. Medicina (Kaunas). 2019;55(4):110.

13. Verster JC, Koenig J. Caffeine intake and its sources: A review of national representative studies. Crit Rev Food Sci Nutr. 2018;58(8):1250-9.

14. Selby CP, Sancar A. Molecular mechanisms of DNA repair inhibition by caffeine. Proc Natl Acad Sci U S A. 1990;87(9):3522-5.

15. Iliakis G, Nusse M, Ganapathi R, Egner J, Yen A. Differential reduction by caffeine of adriamycin induced cell killing and cell cycle delays in Chinese hamster V79 cells. Int J Radiation Oncol Biol Physics. 1986;12:1987-95.

16. Kakuyama (nee Iwazaki) A, Sadzuka Y. Effect of Methylxanthine Derivatives on Doxorubicin Transport and Antitumor Activity. Current Drug Metabol. 2001;2(4):379-95.
17. Sadzuka Y, Mochizuki E, Takino Y. Mechanism of caffeine modulation of the antitumor activity of adriamycin. Toxicol Lett. 1995;75(1-3):39-49.

18. Traganos F, Kapuscinski J, Darzynkiewicz Z. Caffeine modulates the effects of DNA-intercalating drugs in vitro: a flow cytometric and spectrophotometric analysis of caffeine interaction with novantrone, doxorubicin, ellipticine, and the doxorubicin analogue AD198. Cancer Res. 1991;51(14):3682-9.

19. Traganos F, Kaminska-Eddy B, Darzynkiewicz Z. Caffeine reverses the cytotoxic and cell kinetic effects of Novantrone (mitoxantrone). Cell Prolif. 1991;24(3):305-19.

20. Piosik J, Gwizdek-Wiśniewska A, Ulanowska K, Ochociński J, Czyz A, Wegrzyn G. Methylxanthines (caffeine, pentoxifylline and theophylline) decrease the mutagenic effect of daunomycin, doxorubicin and mitoxantrone. Acta Biochim Pol. 2005;52(4):923-6.

21. Nahon E, Best-Belpomme M, Saucier JM. Analysis of the DNA topoisomerase-II-mediated cleavage of the long terminal repeat of Drosophila 1731 retrotransposon. Eur J Biochem. 1993;218(1):95-102.

22. Kimura H, Aoyama T. Decrease in sensitivity to ethidium bromide by caffeine, dimethylsulfoxide or 3-aminobenzamide due to reduced permeability. J Pharmacobiodynamics. 1989;12(10):589-95.

23. Martins IL, Miranda JP, Oliveira NG, Fernandes AS, Gonçalves S, Antunes AM. Synthesis and biological activity of 6-selenocaffeine: potential modulator of chemotherapeutic drugs in breast cancer cells. Molecules. 2013;18(5):5251-64.

24. Hertz E, Cadoná FC, Machado AK, Azzolin V, Holmrich S, Assmann C, Ledur P, Ribeiro EE, DE Souza Filho OC, Mânica-Cattani MF, DA Cruz IB. Effect of Paullinia cupana on MCF-7 breast cancer cell response to chemotherapeutic drugs. Mol Clin Oncol. 2015;3(1):37-43.

25. Hill GM, Moriarity DM, Setzer WN. Attenuation of cytotoxic natural product DNA intercalating agents by caffeine. Sci Pharm. 2011;79(4):729-47.

Cite this article as: Georgiev KD, Slavov IJ, Iliev IA. In vitro evaluation of combination effects of doxorubicin with methylxanthine fractions isolated from Bancha and $\mathrm{Pu}$-erh teas against breast cancer cells. Int J Basic Clin Pharmacol 2019;8:2167-71. 